\title{
Toxicity evaluation of new agricultural fungicides in primary cultured cortical neurons
}

Jorge Regueiro a,b, Nair Olguín a , Jesús Simal-Gándara ${ }^{\text {b }}$, Cristina Suñol ${ }^{\text {a,* }}$

a Department of Neurochemistry and Neuropharmacology, Institut d'Investigacions Biomèdiques de Barcelona (IIBB), Consejo Superior de Investigaciones Científicas (CSIC), IDIBAPS, CIBERESP, Barcelona, Spain

${ }^{b}$ Department of Analytical Chemistry and Food Science, Nutrition and Bromatology Group, Faculty of Food Science and Technology, University of Vigo, Ourense Campus, Ourense, Spain

*Corresponding author. Tel.: +34 933638318

E-mail address: csenqi@iibb.csic.es 


\begin{abstract}
Fungicides are crucial for food protection as well as for the production of crops of suitable quality and quantity to provide a viable economic return. Like other pesticides, fungicides are widely sprayed on agricultural land, especially in wine-growing areas, from where they can move-off after application. Furthermore, residues of these agrochemicals can remain on crops after harvest and even after some food processing operations, being a major exposure pathway. Although a relatively low toxicity has been claimed for this kind of compounds, information about their neurotoxicity is still scarce.

In the present study, nine fungicides recently approved for agricultural uses in the EU —ametoctradin, boscalid, cyazofamid, dimethomorph, fenhexamid, kresoxim-methyl, mepanipyrim, metrafenone and pyraclostrobin - have been evaluated for their toxicity in primary cultured mouse cortical neurons. Exposure to $0.1 \square 100 \mu \mathrm{M}$ for 7 days in vitro resulted in a dose-dependent toxicity in the MTT cell viability assay. Strobilurin fungicides kresoximmethyl (KR) and pyraclostrobin (PY) were the most neurotoxic compounds (lethal concentration 50 were in the low micromolar and nanomolar levels, respectively) causing a rapid raise in intracellular calcium $\left[\mathrm{Ca}^{2+}\right]_{i}$ and strong depolarization of mitochondrial membrane potential. KR- and PY-induced cell death was reversed by the calcium channels blockers MK-801 and verapamil, suggesting that calcium entry through NMDA receptors and voltage-operated calcium channels are involved in KR- and PY-induced neurotoxicity. These results highlight the need for further evaluation of their neurotoxic effects in vivo.
\end{abstract}

Keywords: cortical neurons; fungicides; neurotoxicity; calcium channels; mitochondrial membrane potential; strobilurin 


\section{Introduction}

In recent years, the agricultural industry has experienced strong market and technological competition among the producing countries, resulting in increased production yields while reducing costs for both producers and consumers. In this regard, pesticides are of paramount importance since they allow controlling insect or fungal infestations or growth of weeds, either to handle immediate infestations or to anticipate long-lasting problems (Regueiro et al., 2015). Among them, fungicides are used to manage fungal disease organisms on growing crops, or used as a post-harvest treatment to prevent fungi or molds causing food to rot during storage or transport. Therefore, fungicides have become essential for food protection as well as for maintaining healthy crops, and consistent yields of high quality produce. In fact, fungicides accounted for over $52 \%$ of all plant protection products used in the European Union (EU) in 2003, with an estimated consumption above 100 kilotons (Eurostat, 2007). Like other pesticides, fungicides are widely sprayed on agricultural land and therefore they can move-off of fields after application, becoming a potential health risk not only for farm workers, but also for residents and children by exposure through the air, soil and water environment (Kamel and Hoppin, 2004). Furthermore, residues of these agrochemicals can remain on crops after harvest and even after some food processing operations (Kaushik et al., 2009).

Because of the growing health concerns about the use of ethylene-bis-dithiocarbamate (EBDC) fungicides, especially maneb and mancozeb (Bjørling-Poulsen et al., 2008; Domico et al., 2006), a number of fungicides showing new modes of action have been released in the recent years. These include compounds which affect cell wall biosynthesis in fungal cells (dimethomorph), sterol biosynthesis in membranes (fenhexamid), amino acid and protein synthesis (mepanipyrim), fungal respiration (ametoctradin, boscalid, cyazofamid, kresoximmethyl and pyraclostrobin) or even with unknown mode of action (metrafenone) (FRAC, 2014). Some of them have been very recently included in EU list of authorized plant protection 
products (Table 1) according to Commission Regulation (EC) No 1107/2009 concerning the "placing of plant protection products on the market" (European Commision, 2009). The main properties of these new fungicides are their broad spectrum of action, their special penetration and redistribution properties and their long-term stability, which results in better long-term efficacy, allowing the use of lower concentrations of active substances (Wightwick et al., 2010). These fungicides are used to treat and prevent a broad range of fungal diseases such as late blight and downey mildew on potatoes, eyespot and powdery mildew on cereals, grey mould on strawberries, grapes, tomatoes and cucumbers, or scab on apples and pears (PPDB, 2014). They have also been proposed as effective agents against the fungal production of aflatoxins (Sakuda et al., 2014).

Recent studies suggest that exposure to certain agrochemicals, including fungicides such maneb and mancozeb, may be involved in the development of neurodegenerative disorders such as Parkinson’s disease (Bjørling-Poulsen et al., 2008; Costello et al., 2009). Although a relatively low toxicity is claimed for the newly formulated fungicides, which acceptable daily intakes (ADI) have been established from 0.02 to $10 \mathrm{mg} / \mathrm{kg}$ body weight (Table 1 ), little is known regarding their contribution to neuronal toxicity. Thus, the aim of the present work was to investigate the toxic effects of nine recently approved fungicides with different modes of action on primary cultured cortical neurons.

\section{Materials and methods}

\subsection{Materials}

Pregnant NMRI mice (16th gestational day) were obtained from Charles River/Iffa Credo (Saint Germain-sur-l'Arbreste, France). Plastic multi-well culture plates were purchased from Nunc (Rockilde, Denmark). Fetal bovine serum (FBS) was from Gibco (Invitrogen, Barcelona, Spain). Dulbecco's modified Eagle's minimum essential medium (DMEM) was obtained from 
Biochrom (Berlin, Germany). Isofluorane (FORANE) was from Abbot Laboratories (Madrid, Spain). Fluo-3 acetoxymethyl ester (Fluo-3/AM), rhodamine-123 (Rho-123) and pluronic F127 were from Invitrogen (Carlsbad, CA, USA). Ametoctradin (AM), boscalid (BO), cyazofamid (CY), dimethomorph (DI), fenhexamid (FE), kresoxim-methyl (KR), mepanipyrim (MY), metrafenone (ME) and pyraclostrobin (PY) were Pestanal Grade standards, of certified purity from 97.9 to $99.9 \%$, from Sigma (St. Louis, MO, USA). Dimethyl sulfoxide (DMSO), glacial acetic acid, formic acid ( $\geq 98 \%)$, ethanol, methanol, acetonitrile, poly-D-lysine, trypsin, soybean trypsin inhibitor, bovine serum albumin (BSA), DNAse, HEPES, (+)-MK-801 hydrogen maleate (MK-801), ( \pm )-verapamil hydrochloride, antimicyne A, 3-(4,5dimethythiazol-2-yl)-2,5-diphenyl-tetrazolium bromide (MTT), 2',7'-dichlorofluorescin diacetate (DCFH-DA), Triton-X 100 and sodium dodecyl sufate (SDS) were obtained also from Sigma. D-(+)-glucose monohydrate was purchased from Merck (Darmstadt, Germany).

\subsection{Instrumentation}

All absorbance measurements were performed on a microplate spectrophotometer Multiskan Spectrum from Thermo Fischer Scientific (San Jose, CA, USA). A microplate spectrofluorometer Spectramax Gemini XS from Molecular Devices (Wokingham, UK) was used for all fluorescence readings.

\subsection{Neuronal Cultures}

Primary cultures of cortical neurons were prepared from cerebral cortices of 16th gestational day mice fetuses as previously described (Briz et al., 2010; Solà et al., 2011). Pregnant animals were anesthetized with isofluorane, killed by cervical dislocation, and the fetuses were extracted. Cortices were dissected with forceps and mechanically minced, and cells were then dissociated by mild trypsinization $0.02 \%(\mathrm{w} / \mathrm{v})$ at $37{ }^{\circ} \mathrm{C}$ for $10 \mathrm{~min}$ followed by trituration in a 
DNAse solution $0.004 \%(\mathrm{w} / \mathrm{v})$ containing soybean trypsin inhibitor $0.05 \%(\mathrm{w} / \mathrm{v})$. The cells were then suspended in DMEM containing $31 \mathrm{mM}$ glucose, and $0.2 \mathrm{mM}$ glutamine supplemented with p-aminobenzoate, insulin, penicillin, and $10 \%$ fetal bovine serum. The cell suspension $\left(1.5 \times 10^{6}\right.$ cells per milliliter $)$ was seeded in 6 - or 96 -well plates precoated with poly-D-lysine and incubated in a humidified $5 \% \mathrm{CO}_{2} / 95 \%$ air atmosphere at $37{ }^{\circ} \mathrm{C}$. A mixture of $5 \mu \mathrm{M}$ 5-fluoro-2'-deoxyuridine and $20 \mu \mathrm{M}$ uridine was added after 1 day in vitro (DIV) to prevent glial proliferation. By using this protocol $94 \%$ of the cells are neurons (as identified by immunostaining with tau antibody) and $2 \%$ of the cells are astrocytes (as identified by immunostaining with GFAP antibody). Animals were handled in compliance with protocols approved by the Generalitat de Catalunya Spain, following the EU guidelines.

\subsection{Chemical treatments}

Stock solutions of each fungicide were prepared in DMSO and then stored at $-20{ }^{\circ} \mathrm{C}$. Different working standard solutions were made by appropriate dilution in DMSO and then further diluted in the culture medium so that the final organic solvent concentration never exceeded $0.5 \%(\mathrm{v} / \mathrm{v})$, which was not cytotoxic.

For prolonged exposure periods, neurons were treated at 1 DIV and exposed during 7 days. For short-term exposure experiments, mature cultured neurons were exposed to the fungicides at 7 DIV for periods of time $\leq 24 \mathrm{~h}$. The medium was not changed until the completion of the experiments.

\subsection{Cell viability}

Following each exposure period, cell viability was first assessed by visual inspection under phase-contrast microscopy and then by the MTT assay, which is based on the reduction by viable cells of 3-(4,5-dimethythiazol-2-yl)-2,5-diphenyl-tetrazolium bromide (MTT) to a 
formazan product via a group of nonspecific mitochondrial dehydrogenases. Briefly, a MTT solution in phosphate buffered saline (PBS) was added to each well to a final concentration of $5 \mathrm{mg} / \mathrm{mL}$ and cells were incubated for $3 \mathrm{~h}$ at $37{ }^{\circ} \mathrm{C}$. MTT solution was removed and 100 $\mu \mathrm{L} /$ well of SDS $10 \%(\mathrm{w} / \mathrm{v})$ in water were added and allowed to dissolve the intracellular formazan crystals overnight at $37^{\circ} \mathrm{C}$ in darkness. Absorbance was measured at $570 \mathrm{~nm}$ with background subtraction. Cell viability was expressed as a percentage of the controls (cells exposed to the DMSO).

Additionally, cell viability was evaluated by the propidium iodide (PI) assay as described by Rosa et al. (Rosa et al., 1997). This fluorescent dye rapidly enters cells with damaged membranes and binds to nucleic acids, rendering them brightly fluorescent, whereas it is excluded by living cells (Macklis and Madison, 1990). A PI solution in PBS was added to each well to a final concentration of $10 \mu \mathrm{g} / \mathrm{mL}$ and cells were incubated for $1 \mathrm{~h}$ at $37^{\circ} \mathrm{C}$.

\subsection{Mitochondrial membrane potential $\left(\Delta \Psi_{m}\right)$}

Changes in mitochondrial membrane potential were monitored using rhodamine-123 (Rho123), a cell permeable cationic dye, which is rapidly sequestered by active mitochondria. Depolarization of the membrane results in the release of Rho-123 from the mitochondria and the subsequent increase of fluorescence due to the dequenching of the dye. Cells grown for 7 DIV in 96-well plates were washed twice with Hank's buffered salt solution (HBSS) (1.3 mM $\mathrm{CaCl}, 5.4 \mathrm{mM} \mathrm{KCl}, 0.4 \mathrm{mM} \mathrm{KH} \mathrm{PO}_{4}, 0.5 \mathrm{mM} \mathrm{MgCl}, 0.4 \mathrm{mM} \mathrm{MgSO}_{4}, 137 \mathrm{mM} \mathrm{NaCl}, 4.2 \mathrm{mM}$ $\mathrm{NaHCO}_{3}, 0.3 \mathrm{mM} \mathrm{Na} \mathrm{HPO}_{4}, 8 \mathrm{mM}$ HEPES, and $5.5 \mathrm{mM}$ glucose, adjusted to $\mathrm{pH} 7.4$ ) and incubated with $10 \mu \mathrm{M}$ Rho-123 for $15 \mathrm{~min}$ at $37^{\circ} \mathrm{C}$. Cells were washed again to discard the non-retained Rho-123 and the chemical exposure was performed by adding the fungicide immediately. After $1 \mathrm{~h}$ exposure, fluorescence was determined at $485 \mathrm{~nm}$ excitation and 530 $\mathrm{nm}$ emission wavelengths. Responses were normalized to maximal fluorescence, obtained after 
treatment with a revealing solution of acetic acid/ethanol $(1: 2, \mathrm{v} / \mathrm{v})$ or after treatment of sister cells with $15 \mu \mathrm{M}$ antimycin (ANT).

\subsection{Determination of intracellular calcium}

Intracellular calcium levels were measured by using the fluorescent calcium indicator fluo-3 acetoxymethyl ester (Fluo-3/AM). This cell-permeable dye is hydrolyzed by intracellular esterases and trapped in cells as Fluo-3, which increases its fluorescence upon binding of $\mathrm{Ca}^{2+}$. Cells grown for 7 DIV in 96-well plates were washed twice with HBSS and incubated for $1 \mathrm{~h}$ at $37{ }^{\circ} \mathrm{C}$ with $9 \mu \mathrm{M}$ Fluo-3/AM in HBSS containing $0.5 \%$ DMSO and $0.08 \%$ of the nonionic surfactant pluronic F-127. Excess Fluo-3/AM was rinsed away, and the cells were treated with the studied fungicides in HBSS. Fluorescence was immediately determined at $485 \mathrm{~nm}$ excitation and $530 \mathrm{~nm}$ emission wavelengths. Results were expressed as the intracellular calcium percentage of the untreated cells (DMSO).

\subsection{Cellular uptake of fungicides}

\subsubsection{Extraction and cleanup}

Cells were grown in 6-well plates and after 7 DIV they were exposed to the selected fungicides $(100 \mu \mathrm{M}$ AM, $100 \mu \mathrm{M} \mathrm{CY}, 10 \mu \mathrm{M}$ KR and $1 \mu \mathrm{M} \mathrm{PY})$ for $8 \mathrm{~h}$. At the end of the experiment, culture medium was removed and cells were rinsed three times with HBSS. Cells were then scrapped into $2 \mathrm{~mL}$ ultrapure water and disrupted by sonication ( $5 \mathrm{x} 10 \mathrm{~s}$ pulses, $30 \%$ power) on ice with an ultrasonic homogenizer. Protein content of the cell lysates was determined by the Bradford assay (Bio-Rad Laboratories, München, Germany) using bovine serum albumin (BSA) as protein standard.

Fungicides were extracted from the homogenates by solid-phase extraction (SPE) using polymeric SPE cartridges Strata-X (200 mg, $6 \mathrm{~mL}$ ) from Phenomenex (Torrance, California, 
USA). Briefly, $1.8 \mathrm{~mL}$ sample were loaded into the SPE cartridge previously conditioned with $5 \mathrm{~mL} 2 \%(\mathrm{v} / \mathrm{v})$ formic acid in methanol followed by $5 \mathrm{~mL}$ water. After washing with $2 \mathrm{~mL}$ water, fungicides were eluted with $10 \mathrm{~mL} 2 \%$ (v/v) formic acid in methanol. The eluate was brought to dryness under a gentle stream of nitrogen, reconstituted in $300 \mu \mathrm{L}$ of methanol/water/formic acid (30:69.8:0.2, v/v/v), filtered through a 0.20 $\mu \mathrm{m}$ PTFE syringe filter and analyzed by HPLC-DAD/ESI-MS/MS.

Recoveries for AM, CY, KR and PY were evaluated at 0.5 and $50 \mathrm{ng} / \mathrm{mL}$. Values ranged from $88 \%$ to $99 \%$ at both spiked levels. Limits of quantification (LOQ), defined for a signal-to-noise ratio of $10(\mathrm{~S} / \mathrm{N}=10)$, below $0.3 \mathrm{ng} / \mathrm{mL}$ were obtained for these four compounds.

The cellular uptake of fungicides was normalized to milligrams of cell protein. The percentage of cellular uptake was calculated with respect to the amount of fungicides initially present in the culture medium.

\subsubsection{HPLC-DAD/ESI-MS/MS analyses}

Analyses were carried out in a Thermo HPLC system (Thermo Fisher Scientific, San Jose, CA, USA) consisting of a TSP AS3000 autosampler with column oven, a Surveyor LC quaternary pump, a Surveyor PDA diode array detector (DAD) coupled to a triple stage quadrupole mass spectrometer TSQ Quantum Access equipped with a electrospray ionization (ESI) source. Instrument control and data acquisition were performed with Xcalibur 2.0 software also from Thermo.

Chromatographic separation of the fungicides was performed on a reversed-phase column Luna C18(2) $(150 \times 3.0 \mathrm{~mm}, 3 \mu \mathrm{m})$ from Phenomenex, maintained at $30^{\circ} \mathrm{C}$. Mobile phases A and B were respectively, water/formic acid (99.8:0.2, v/v) and acetonitrile/water/formic acid $(95: 4.8: 0.2, \mathrm{v} / \mathrm{v} / \mathrm{v})$. The following linear gradient was used: hold at $65 \% \mathrm{~A}$ for $1 \mathrm{~min}$, decreased to $20 \%$ A over $6 \mathrm{~min}$, decreased to $5 \% \mathrm{~A}$ over $13 \mathrm{~min}$ and hold for $2 \mathrm{~min}$, then returned to initial 
conditions over $2 \mathrm{~min}$ and re-equilibrated for $7 \mathrm{~min}$. The flow rate and the injection volume were set at $0.4 \mathrm{~mL} / \mathrm{min}$ and $20 \mu \mathrm{L}$, respectively.

UV/Vis spectra were recorded from 200 to $600 \mathrm{~nm}$ with the DAD, whereas the mass spectrometer was operated in the positive ESI mode at a spray voltage of $4500 \mathrm{~V}$. Nitrogen (>99.98\%) was employed as sheath gas and auxiliary gas at pressures of 40 and 10 arbitrary units, respectively. The capillary temperature was set to $270{ }^{\circ} \mathrm{C}$. The detection was performed in the multiple reaction monitoring (MRM) mode using argon (>99.999\%) as collisioninduced-dissociation (CID) gas at 1.5 mTorr. Optimized MS/MS ion transitions for each compound are detailed in Table 2. The linearity of the method was tested using standard solutions at six concentration levels from $5 \mathrm{ng} / \mathrm{mL}$ to $1000 \mathrm{ng} / \mathrm{mL}$ for all compounds. Calibration curves were found to be linear in the studied ranges with determination coefficients $\left(\mathrm{R}^{2}\right) \geq 0.9941$ and $\operatorname{RSD}(\mathrm{n}=3) \leq 7 \%$.

\subsection{Data Analysis}

Data are expressed as mean \pm standard error of the mean (SEM) of at least three experiments from independent culture batches, each performed in triplicate; the number of independent cultures (n) for each experiment is indicated in the corresponding figure caption. Statistical significance was determined by one-way ANOVA followed by Dunnett's multiple comparison tests when comparing more than two groups, and by two-way ANOVA followed by Bonferroni's test when comparing two factors. Dose-response curves were fitted to sigmoidal curves. All statistical calculations were made using the software package GraphPad Prism version 4.0 (GraphPad Software, San Diego, CA).

\section{Results}

\subsection{Effects of short- and long-term exposure on cell viability}


Exposure of cultured cortical neurons to $100 \mu \mathrm{M}$ of the fungicides cyazofamid (CY), kresoxim-methyl (KR) and pyraclostrobin (PY) for $24 \mathrm{~h}$ resulted in a significant decrease in cell viability $>20 \%$ (the considered Low Effect Level -LOEL) (Fig. 1A, white bars). In agreement with the general concept that toxicity is dependent on both drug concentration and exposure time, the toxicity of the fungicides increased after long-term exposure and cell viability was significantly reduced $(p<0.001)$ by all the evaluated fungicides $(\mathrm{CY}, \mathrm{KR}, \mathrm{PY}$ and ametoctradin -AM-, boscalid -BO-, dimethomorph -DI-, fenhexamid -FE-, mepanipyrim MY- and metrafenone -ME) (Fig. 1A, black bars). Concentration-dependent behavior was observed for all fungicides, being PY and KR the most neurotoxic compounds, exhibiting LC50 values in the nanomolar and low micromolar range, respectively, when the exposure was continued for several days. Furthermore, all the compounds except KR showed higher toxicity at the longer exposure period. The results were confirmed by phase-contrast microscopic visualization and propidium iodide uptake (data not shown). Fig. 1B shows the concentration response curves for the effects of fungicides on cell viability after short exposure (24 hours in vitro) and continuous exposure ( 7 days in vitro). Table 3 shows the concentration that produces $50 \%$ of cell cytotoxicity (LC50). CY was tested up to $30 \mu \mathrm{M}$ in the continuous exposure because of the formation of crystals after two days of exposure at higher concentrations. For comparison, we also determined the toxicity of the widely used fungicide maneb in cultured cortical neurons after continuous exposure for 7 days in vitro. LC50 value was $26 \pm 2 \mu \mathrm{M}$ $(n=3)$. Furthermore, for the most toxic compound PY no differences were found when mature cells were continuously exposed from DIV 7 to DIV 13 (LC50: $0.05 \pm 0.01 \mu \mathrm{M}, \mathrm{n}=6$ ) with respect to neurons continuously exposed during the first week in culture (LC50: $0.06 \pm 0.01$ $\mu \mathrm{M}, \mathrm{n}=5)$.

Furthermore, in order to determine if there was any relationship between intracellular concentration and the observed cell death, cellular content was quantified for AM, CY, KR and 
PY (Table 4). AM was evaluated as it did not induce major toxicity in neurons whereas the other three compounds exhibited the lowest LC50 values in both short- and long-term exposures. To avoid significant metabolism of the fungicides, the cells were exposed for a short period (8 hours). CY intracellular content and its percentage of cellular uptake were significantly higher than those of $\operatorname{AM}(p<0.01)$. On the other hand, assuming that accumulation of PY and KR was lineal in the low micromolar range $(1-10 \mu \mathrm{M})$, the intracellular content and percentage of cellular uptake of PY were significantly higher than that of $\mathrm{KR}(p<0.01)$. These findings were in relation with the highest toxicity of CY compared to $\mathrm{AM}$ and of PY compared to KR.

\subsection{Pyraclostrobin (PY) and kresoxim-methyl (KR) rise intracellular calcium $\left[\mathrm{Ca}^{2+}\right]_{i}$ and induce mitochondrial membrane potential $\left(\Delta \Psi_{m}\right)$ depolarization}

It is well known that when $\mathrm{Ca}^{2+}$ homeostasis is disrupted, this ion can behave as a powerful activator of multiple damaging processes. We determined whether fungicides increased cytosolic calcium. Fig. 2A shows that PY and KR increased $\left[\mathrm{Ca}^{2+}\right]_{\mathrm{i}}$ in a concentrationdependent manner. Results showed a significant increase $(p<0.01)$ of $\left[\mathrm{Ca}^{2+}\right]_{\mathrm{i}}$ when cells were exposed to $\geq 1 \mu \mathrm{M}$ PY $(26.7 \pm 2.8 \%)$ and to $\geq 10 \mu \mathrm{M} \mathrm{KR}(31.7 \pm 4.4 \%)$ in comparison to control conditions (Fig. 2A). AM, DI, FE, ME and MY (up to $100 \mu \mathrm{M}$ ) and CY (up to $30 \mu \mathrm{M}$ ) did not induce by themselves an increase of intracellular calcium (data not shown). The increase of intracellular calcium induced by PY and KR was significantly reduced in a nominal calcium-free medium (Fig. 2B).

The inhibition of mitochondrial complex III is one of the proposed mechanisms of action for several fungicides, among them AM, CY, KR and PY (see Table 1). Furthermore, a rise in intracellular calcium may lead to the loss of mitochondrial potential (Duchen, 2000). Five out of the nine evaluated fungicides $-\mathrm{CY}, \mathrm{FE}, \mathrm{KR}, \mathrm{ME}$ and $\mathrm{PY}-$ were able to significantly 
induce $(p<0.01)$ mitochondrial membrane depolarization when tested up to $100 \mu \mathrm{M}$ in cultured cortical neurons (Fig. 3A). PY, KR and CY were the compounds that produced highest mitochondrial membrane depolarization with EC50 values of $5 \pm 1 \mu \mathrm{M}, 29 \pm 9 \mu \mathrm{M}$ and $20 \pm 5$ $\mu \mathrm{M}(\mathrm{n}=3)$, respectively (Fig. 3B).

\subsection{Neuroprotection with NMDA receptor antagonist and L-type $\mathrm{Ca}^{2+}$ channel blocker}

Both elevated intracellular calcium and reduced mitochondrial membrane potential represent major pathophysiologic conditions affecting neuronal viability. Furthermore, the depolarization of mitochondrial membrane may be the result of increasing accumulation of calcium within mitochondria and, viceversa, an increase of cytosolic calcium may be the consequence of disrupted integrity of the mitochondria. Therefore, we evaluated whether blocking two main pathways leading to increased intracellular calcium (the N-methyl-D-aspartate receptor NMDAR- and the voltage-operated $\mathrm{Ca}^{2+}$ channels -VOCC) would have a protective effect against fungicides-induced toxicity. Results of cell viability in the presence of $1 \mu \mathrm{M}$ PY or 10 $\mu \mathrm{M}$ KR together with calcium channel blockers (10 $\mu \mathrm{M}$ of MK-801 for the NMDAR and 50 $\mu \mathrm{M}$ of verapamil for the VOCC) are depicted in Fig. 4. MK-801 significantly protected cells against fungicide effects $(p<0.01)$ and the neuroprotective effect was still increased by a combination of MK-801 and verapamil $(p<0.001)$.

\section{Discussion}

All the tested fungicides produced a reduction of cell viability. Whereas four of these compounds (BO, CY, KR and PY) displayed a toxic effect after a short time of exposure (24 hours), all nine fungicides resulted toxic after 7 days of exposure. Those acting by inhibiting the mitochondrial respiration complex III (CY, KR and PY but not AM, see Table 1) displayed the higher levels of toxicity. This complex is one of the four multiprotein complexes within the 
inner mitochondrial membrane involved in the passage of electrons in the respiratory chain. The well-known electron transporter ubiquinone or coenzyme-Q (CoQ) binds to complex III at the $\mathrm{Q}_{\mathrm{o}}$ (quinol-oxidizing) site when it is reduced and at the $\mathrm{Q}_{\mathrm{i}}$ (quinol-reducing) site when it is oxidized allowing the electron movement. $\mathrm{CY}$ seems to bind at the quinol-reducing site $\mathrm{Q}_{\mathrm{i}}$ whereas KR and PY seem to bind at the quinol-oxidizing site $\mathrm{Q}_{\mathrm{o}}$ (FRAC, 2014; Li et al., 2014). The inhibition of any of these sites would inhibit the natural electron transport and finally induce decreased ATP generation and mitochondrial membrane depolarization eventually leading to increased cytosolic calcium and to cell death (Boutilier, 2001; Chinopoulos and Adam-Vizi, 2010; Pham et al., 2000; Zhang et al., 1998). It is worth to note that the toxicity of PY and KR found in this work was higher than that induced by the widely used fungicide maneb in cortical neurons.

In this work we have determined the effect of new fungicides with different mode of action on cultured cortical neurons. In agreement with their mode of action (respiration inhibition of mitochondrial complex III), CY, KR and PY were able to significantly induce mitochondrial membrane depolarization in mature neurons. This may be related to the alteration of electron transport and alteration of the proton gradient across the mitochondrial inner membrane, thereby breaking down the mitochondrial membrane potential (Pham et al., 2000). The affinity of these compounds for the porcine mitochondrial complex III (PY > KR > CY) (Li et al., 2014; Zhao et al., 2009) has a pattern similar to that shown in this work for the mitochondrial membrane depolarization, the increase of cytosolic calcium and the loss of cell viability in cultured cortical neurons. These three compounds induced the higher cell death as well as the higher level of membrane depolarization and increased cytosolic calcium in comparison to the control condition. The fact that the increase in intracellular calcium induced by PY and KR was abolished in the absence of external calcium suggests an influx of calcium ions through membrane calcium channels (either voltage- or NMDA receptor-operated). This increase of 
cytosolic calcium can lead to a neurotoxic cascade eventually inducing cell death. In this sense, the blockage of membrane calcium channels by MK-801 (antagonist of the glutamate-NMDA receptor) and by verapamil (antagonist of voltage-operated $\mathrm{Ca}^{2+}$ channels) resulted in neuroprotection. When both NMDA and L-type channels where unable to conduct calcium ions, there was a neuroprotective effect since cell death was further diminished. In this case, a reduced entrance of $\mathrm{Ca}^{2+}$ ions may be delaying calcium overload and cell death (Dong et al., 2006). Nonetheless, the imbalance of $\left[\mathrm{Ca}^{2+}\right]_{\mathrm{i}}$ together with the mitochondrial membrane depolarization may be responsible for cell death.

On the other hand, FE and ME also induced mitochondrial membrane depolarization. FE inhibits sterol biosynthesis and specifically targets 3-keto reductase (Debieu et al., 2001). There is no known mode of action for ME, however it likely disturbs the organization of the actin cytoskeleton (Opalski et al., 2006). Both inhibition of 3-keto reductase and disruption of the actin dynamics may indirectly affect mitochondrial membrane fluidity and function (Breitenbach et al., 2005; Vrablik and Watts, 2012). Both CY, FE and ME displayed similar LC50 values $(\sim 25 \mu \mathrm{M})$ against cortical neurons viability when they were exposed to the fungicides for 7 days in vitro, despite the fact that $\mathrm{CY}$ was much more potent than $\mathrm{FE}$ and $\mathrm{ME}$ in inducing mitochondrial membrane depolarization (Fig. 3A). This suggests that in addition to mitochondrial failure, alteration of lipid biosynthesis and of actin dynamics may play a role on the cytotoxic effects of FE and ME, respectively. On the other hand, MY scarcely induced cytotoxic effects in cortical neurons (LC50 values around $100 \mu \mathrm{M}$ after seven days of exposure in vitro). Unlike $\mathrm{FE}$ and $\mathrm{ME}$, the acute exposure to MY did not alter mitochondrial membrane potential in cultured cortical neurons. In relation to this, a similar exposure to MY on cultured hepatocytes did not reduce the cellular ATP content (Terada et al., 1999).

Finally, neither AM nor BO reduced cell viability by more than $50 \%$ even after prolonged exposure for 7 days in vitro to $100 \mu \mathrm{M}$ of each compound. Despite the proposed mechanism of 
action for AM is through the inhibition of the mitochondrial complex III, it exerts a unique mode of action by binding to the very specific stigmatellin sub-site at the $\mathrm{Q}_{0}$, being currently the only fungicide belonging to this category (FRAC, 2014). Thus, the difference in toxicity observed between the two representatives of the strobilurin family, KR and PY, and the AM could be explained based on their differential binding. Although all three compounds bind to the $\mathrm{Q}_{\mathrm{o}}$ site of the mitochondrial complex III, strobilurin fungicides bind the heme $b_{l}$ proximal domain, whereas AM has been reported to act by binding in the same domain as stigmatellin, i.e. in the distal pocket close to the Rieske iron-sulfur protein (Crofts et al., 1999; Fisher and Meunier, 2008).

In the case of $\mathrm{BO}$, this compound inhibits mitochondrial complex II which will not have a direct effect on the electron flux to the mitochondrial respiratory chain. Instead, the inhibition of complex II would disturb the tricarboxylic acid cycle (Nicholls, 2002). Therefore we would not expect that $\mathrm{BO}$ depolarized the mitochondrial membrane potential like complex III inhibitors PY, KR and CY did.

In summary, we have reported that the fungicides PY, KR and CY are incorporated into neurons in primary cultures of cortical neurons. In doing so, they target the mitochondria as they do as pest controllers, disrupt intracellular calcium homeostasis and induce cell death. It is noteworthy that the neuronal toxicity was induced at concentrations lower than those inducing toxicity in human lymphocytes (Çayır et al., 2014). The higher energy demand of neurons in relation to other cells in mammals may make neurons to be critically susceptible to lipophilic compounds that interfere with the mitochondrial respiratory chain. Among them, PY showed the highest neurotoxicity with a LC50 in the nanomolar level, above 400-fold higher than the toxicity observed under the same conditions for maneb, a fungicide which has been recently related with an increased risk of Parkinson's disease. Thus, these results highlight the need for further evaluation of its neurotoxic effects in vivo. 
Regarding AM, which has been very recently approved in the EU for its use in crop protection products, it was observed a much lower toxicity (LC50 >100 $\mu \mathrm{M})$ which is in agreement with the higher acceptable daily intake established for this fungicide (Table 1).

\section{Acknowledgements}

This research was supported by the projects PI10/00453 and PI13/01252 from the Instituto de Salud Carlos III cofinanced with European Social Funds "A Way to build Europe" and AGL2011-30378-C03-01 of the Spanish Ministries of Health, and Science and Innovation, respectively. J. R. would like to acknowledge the Ministry of Science and Innovation of Spain for his Juan de la Cierva contract. N.O. is recipient of a CSIC JAE-Doc contract from the "Junta para la Ampliación de Estudios" Program cofinanced with European Social Funds. The technical assistance of Elisenda Martí is acknowledged

\section{References}

Bjørling-Poulsen, M., Andersen, H.R., Grandjean, P., 2008. Potential developmental neurotoxicity of pesticides used in Europe. Environ. Health 7, 50. doi:10.1186/1476069X-7-50

Boutilier, R.G., 2001. Mechanisms of cell survival in hypoxia and hypothermia. J. Exp. Biol. 204, 3171-3181.

Breitenbach, M., Laun, P., Gimona, M., 2005. The actin cytoskeleton, RAS-cAMP signaling and mitochondrial ROS in yeast apoptosis. Trends Cell Biol. 15, 637-639.

Briz, V., Galofré, M., Suñol, C., 2010. Reduction of Glutamatergic Neurotransmission by Prolonged Exposure to Dieldrin Involves NMDA Receptor Internalization and Metabotropic Glutamate Receptor 5 Downregulation. Toxicol. Sci. 113, 138-149. 
Çayır, A., Coskun, M., Coskun, M., 2014. Micronuclei, nucleoplasmic bridges, and nuclear buds induced in human lymphocytes by the fungicide signum and its active ingredients (boscalid and pyraclostrobin). Environ. Toxicol. 29, 723-732.

Chinopoulos, C., Adam-Vizi, V., 2010. Mitochondria as ATP consumers in cellular pathology. Biochimica et Biophysica Acta (BBA)-Molecular Basis of Disease 1802, 221-227.

Costello, S., Cockburn, M., Bronstein, J., Zhang, X., Ritz, B., 2009. Parkinson's Disease and Residential Exposure to Maneb and Paraquat From Agricultural Applications in the Central Valley of California. Am. J. Epidemiol. 169, 919-926.

Crofts, A.R., Barquera, B., Gennis, R.B., Kuras, R., Guergova-Kuras, M., Berry, E.A., 1999. Mechanism of ubiquinol oxidation by the bc 1 complex: different domains of the quinol binding pocket andtheir role in the mechanism and binding of inhibitors. Biochemistry $38,15807-15826$.

Debieu, D., Bach, J., Hugon, M., Malosse, C., Leroux, P., 2001. The hydroxyanilide fenhexamid, a new sterol biosynthesis inhibitor fungicide efficient against the plant pathogenic fungus Botryotinia fuckeliana (Botrytis cinerea). Pest Manage. Sci. 57, 1060-1067.

Domico, L.M., Zeevalk, G.D., Bernard, L.P., Cooper, K.R., 2006. Acute neurotoxic effects of mancozeb and maneb in mesencephalic neuronal cultures are associated with mitochondrial dysfunction. Neurotoxicology 27, 816-825.

Dong, Z., Saikumar, P., Weinberg, J.M., Venkatachalam, M.A., 2006. Calcium in cell injury and death. Annu. Rev. Pathol. Mech. Dis. 1, 405-434.

Duchen, M.R., 2000. Mitochondria and calcium: from cell signalling to cell death. J. Physiol. $529,57-68$.

European Commision, 2009. Regulation (EC) No 1107/2009 of the European Parliament and of the Council of 21 October 2009 concerning the placing of plant protection products 
on the market and repealing Council Directives 79/117/EEC and 91/414/EEC. Official Journal of the European Union L 309, 1-50.

Eurostat, 2007. The use of plant protection products in the European Union: Data 1992-2003. European Commission, Luxembourg.

Fisher, N., Meunier, B., 2008. Molecular basis of resistance to cytochrome bc1 inhibitors. FEMS Yeast Res. 8, 183-192.

FRAC, 2014. FRAC Code List: Fungicides sorted by mode of action. Fungicide Resistance Action Committee (FRAC).

Kamel, F., Hoppin, J.A., 2004. Association of pesticide exposure with neurologic dysfunction and disease. Environ. Health Perspect. 112, 950-958.

Kaushik, G., Satya, S., Naik, S.N., 2009. Food processing a tool to pesticide residue dissipation - A review. Food Res. Int. 42, 26-40.

Li, H., Zhu, X.L., Yang, W.C., Yang, G.F., 2014. Comparative Kinetics of Qi Site Inhibitors of Cytochrome bc1 Complex: Picomolar Antimycin and Micromolar Cyazofamid. Chem. Biol. Drug Des. 83, 71-80.

Macklis, J.D., Madison, R.D., 1990. Progressive incorporation of propidium iodide in cultured mouse neurons correlates with declining electrophysiological status: a fluorescence scale of membrane integrity. J. Neurosci. Methods 31, 43-46.

Nicholls, D.G., 2002. Mitochondrial function and dysfunction in the cell: its relevance to aging and aging-related disease. Int. J. Biochem. Cell B 34, 1372-1381.

Opalski, K.S., Tresch, S., Kogel, K.H., Grossmann, K., Köhle, H., Hückelhoven, R., 2006. Metrafenone: studies on the mode of action of a novel cereal powdery mildew fungicide. Pest Manage. Sci. 62, 393-401. 
Pham, N.A., Robinson, B.H., Hedley, D.W., 2000. Simultaneous detection of mitochondrial respiratory chain activity and reactive oxygen in digitonin-permeabilized cells using flow cytometry. Cytometry 41, 245-251.

PPDB, 2014. The Pesticide Properties Database (PPDB). Agriculture \& Environment Research Unit (AERU), University of Hertfordshire, UK.

Regueiro, J., López-Fernández, O., Rial-Otero, R., Cancho-Grande, B., Simal-Gándara, J., 2015. A Review on the Fermentation of Foods and the Residues of Pesticides Biotransformation of Pesticides and Effects on Fermentation and Food Quality. Crit. Rev. Food Sci. Nutr. 55, 839-863.

Rosa, R., Sanfeliu, C., Suñol, C., Pomés, A., Rodrı, amp, x, guez-Farré, E., Schousboe, A., Frandsen, A., 1997. The Mechanism for Hexachlorocyclohexane-Induced Cytotoxicity and Changes in Intracellular Ca2+Homeostasis in Cultured Cerebellar Granule Neurons Is Different for the $\gamma$ - and $\delta$-Isomers. Toxicol. Appl. Pharmacol. 142, 31-39.

Sakuda, S., Prabowo, D.F., Takagi, K., Shiomi, K., Mori, M., Ōmura, S., Nagasawa, H., 2014. Inhibitory Effects of Respiration Inhibitors on Aflatoxin Production. Toxins (Basel) 6, 1193-1200.

Solà, C., Cristòfol, R., Suñol, C., Sanfeliu, C., 2011. Primary cultures for neurotoxicity testing, Cell Culture Techniques. Springer, pp. 87-103.

Terada, M., Mizuhashi, F., Murata, K., Tomita, T., 1999. Mepanipyrim, a new fungicide, inhibits intracellular transport of very low density lipoprotein in rat hepatocytes. Toxicol. Appl. Pharmacol. 154, 1-11.

Tomlin, C.D.S., (Ed.) In: The e-Pesticide Manual, 13th Edition Version 3.1 (2004). Surrey UK, British Crop Protection Council.

Vrablik, T.L., Watts, J.L., 2012. Emerging roles for specific fatty acids in developmental processes. Genes Dev. 26, 631-637. 
Wightwick, A., Walters, R., Allinson, G., Reichman, S., Menzies, N., 2010. Environmental

Risks of Fungicides Used in Horticultural Production Systems, in: O. Carisse (Ed.), Fungicides. InTech, pp. 273-304.

Zhang, Z., Huang, L., Shulmeister, V.M., Chi, Y.-I., Kim, K.K., Hung, L.-W., Crofts, A.R., Berry, E.A., Kim, S.-H., 1998. Electron transfer by domain movement in cytochrome bc1. Nature 392, 677-684.

Zhao, P.-L., Wang, L., Zhu, X.-L., Huang, X., Zhan, C.-G., Wu, J.-W., Yang, G.-F., 2009. Subnanomolar inhibitor of cytochrome bc 1 complex designed by optimizing interaction with conformationally flexible residues. J. Am. Chem. Soc. 132, 185-194.

\section{Legends}

Figure 1.- Effects of fungicides on cell viability measured by the MTT assay in primary cultures of cortical neurons. A) Cells were acutely exposed to fungicides at day in vitro 7 (DIV 7) for 24 hours (white bars) or continuously exposed from DIV 1 to DIV 8 (black bars). All fungicides were applied at $100 \mu \mathrm{M}$, except for continuous exposure to $\mathrm{CY}$ at $30 \mu \mathrm{M}$ due to solubility problems. Results are expressed as mean $\pm \mathrm{SEM} ; \mathrm{n}=3-4$ cultures. ${ }^{*} p<0.05 ; \# p$ $<0.001$ compared to control cells. B) Concentration-response curves for the effects of fungicides on cell viability in cultured cortical neurons. Solid symbols and lines represent continuous exposure while open symbols and dashed lines represent acute exposure. Results are expressed as mean \pm SEM; $n=3-4$ cultures.

Figure 2.- A) Concentration-response curves for the increase of intracellular calcium induced by PY ( $\boldsymbol{\nabla}$; blue $)$ and KR ( $\bigcirc$; red). Results are means \pm SEM of 3-4 independent experiments. B) The increase of [Ca2+]i induced by $1 \mu \mathrm{M}$ PY (blue bars; diagonal) or $10 \mu \mathrm{M}$ KR (red bars; crossed) was inhibited in the nominal absence of calcium in the medium. Results are mean \pm SEM of 3-4 independent experiments. ** p <0.01 and *** p $<0.001$ with respect to control (black bars) in plain buffer; \#\# p <0.01 and \#\#\# p <0.001 with respect to fungicide treatment in plain buffer. 
Figure 3.- Depolarization of mitochondrial membrane (MM) induced by fungicide exposure. Cells were acutely exposed to fungicides at DIV 7. Values are mean \pm SEM; $n=3$ cultures. Responses are normalized to maximum depolarization induced by $15 \mu \mathrm{M}$ antimycin (ANT). A) Fungicides were tested at $100 \mu \mathrm{M}$, except $\mathrm{KR}$ and PY at $50 \mu \mathrm{M}$. ** p $<0.01, * * * \mathrm{p}<0.001$ compared to control cells. B) Concentration-response curves for PY ( $\boldsymbol{\nabla}$; blue), KR ( $\mathbf{O}$; red) and CY ( $\mathbf{m}$; green).

Figure 4.- Effect of calcium channel antagonists on the reduction of cell viability induced by PY and KR. Cells were continuously exposed to vehicle (DMSO) or fungicides from DIV 1 to DIV 8 in the absence (black bars) or in the presence of $50 \mu \mathrm{M}$ verapamil (red bars; dotted), 10 $\mu \mathrm{M}$ MK-801 (green bars; horizontal lines) or verapamil plus MK-801 (blue bars; vertical lines) from DIV 1 to DIV 8. Results are expressed as mean \pm SEM of 5-6 independent experiments. $* * \mathrm{p}<0.01$ and $* * * \mathrm{p}<0.001$ vs corresponding exposure to fungicide alone. 
Table 1

Structures, characteristics and modes of action of the studied fungicides

\begin{tabular}{|c|c|c|c|c|c|c|}
\hline Fungicide & Structure & Chemical Group & $\log \mathrm{P}^{\mathrm{a}}$ & Mode of action ${ }^{\mathrm{b}}$ & $\begin{array}{l}\text { Approval } \\
\text { year }^{c}\end{array}$ & $\begin{array}{c}\text { ADI } \\
(\mathrm{mg} / \mathrm{kg} \\
\text { bw/d) }\end{array}$ \\
\hline Ametoctradin (AM) & & $\begin{array}{l}\text { Triazolo- } \\
\text { pyrimidylamine }\end{array}$ & 4.4 & $\begin{array}{l}\text { Respiration inhibition of complex III: cytochrome bc1(ubiquinone } \\
\text { reductase) at Qo site, stigmatellin binding sub-site }\end{array}$ & 2013 & 10 \\
\hline Boscalid (BO) & & $\begin{array}{l}\text { Pyridine- } \\
\text { carboxamide }\end{array}$ & 2.96 & Respiration inhibition of complex II: succinate dehydrogenase inhibitors & 2008 & 0.04 \\
\hline Cyazofamid (CY) & & $\begin{array}{l}\text { Cyano- } \\
\text { imidazole }\end{array}$ & 3.2 & $\begin{array}{l}\text { Respiration inhibition of complex III: cytochrome bc1(ubiquinone } \\
\text { reductase) at Qi site }\end{array}$ & 2003 & 0.17 \\
\hline Dimethomorph (DI) & & $\begin{array}{l}\text { Cinnamic acid } \\
\text { amide }\end{array}$ & 2.68 & Cell wall biosynthesis: cellulose synthase & 2007 & 0.05 \\
\hline Fenhexamid (FE) & & Hydroxyanilide & 3.51 & $\begin{array}{l}\text { Sterol biosynthesis in membranes: 3-keto reductase in C4-de-methylation } \\
\text { (erg27) }\end{array}$ & 2001 & 0.2 \\
\hline Kresoxim-methyl (KR) & & Strobilurin & 3.40 & $\begin{array}{l}\text { Respiration inhibition of complex III: cytochrome bc1(ubiquinol oxidase) } \\
\text { at Qo site (cyt b gene) }\end{array}$ & 1999 & 0.4 \\
\hline Mepanipyrim (MY) & & $\begin{array}{l}\text { Anilino- } \\
\text { pyrimidine }\end{array}$ & 3.28 & Amino Acid and Protein Synthesis: methionine biosynthesis (cgs gene) & 2004 & 0.02 \\
\hline Metrafenone (ME) & & $\begin{array}{l}\text { Aryl-phenyl- } \\
\text { ketone }\end{array}$ & 4.3 & Unknown: actin disruption (proposed) & 2007 & 0.25 \\
\hline Pyraclostrobin (PY) & & Strobilurin & 3.99 & $\begin{array}{l}\text { Respiration inhibition of complex III: cytochrome bc1(ubiquinol oxidase) } \\
\text { at Qo site (cyt b gene) }\end{array}$ & 2004 & 0.03 \\
\hline
\end{tabular}

${ }^{\mathrm{a}}$ (Tomlin, 2004); ${ }^{\mathrm{b}}$ (FRAC, 2014); ${ }^{\mathrm{c}}$ (European Commision, 2009); Log $\mathrm{K}_{\text {ow }}$ : octanol-water partition coefficient; ADI: Acceptable Daily Intake 

Table 2

Specific MRM conditions for determination of selected fungicides by LC-ESI-MS/MS

\begin{tabular}{ccccc}
\hline Fungicides & $t_{R}(\min )$ & Parent ion & MS/MS transition & $\mathrm{CE}(\mathrm{eV})$ \\
\hline \multirow{2}{*}{$\mathrm{AM}$} & 10.83 & {$[\mathrm{M}+\mathrm{H}]^{+}$} & $276>176^{\mathrm{a}}$ & 35 \\
\cline { 4 - 5 } & & & $276>149$ & 36 \\
\hline $\mathrm{CY}$ & 13.62 & {$[\mathrm{M}+\mathrm{H}]^{+}$} & $325>108^{\mathrm{a}}$ & 15 \\
\cline { 4 - 5 } & & & $325>280$ & 12 \\
\hline $\mathrm{KR}$ & 13.74 & {$[\mathrm{M}+\mathrm{H}]^{+}$} & $314>222^{\mathrm{a}}$ & 15 \\
\cline { 4 - 5 } & & & $314>235$ & 12 \\
\hline $\mathrm{PY}$ & 14.51 & {$[\mathrm{M}+\mathrm{H}]^{+}$} & $388>194^{\mathrm{a}}$ & 15 \\
\cline { 4 - 5 } & & & $388>164$ & 16
\end{tabular}

${ }^{\mathrm{a}}$ Quantifier transition; CE: collision energy 
Table 3.- LC50 values for the cytotoxicity of the fungicides in cortical neurons after exposure for 1 DIV (acute exposure) and 8 DIV (continuous exposure). Values are mean \pm SEM of $3-5$ experiments. ${ }^{*} p<0.05$; \# $P<0.001$ with respect to acute exposure

\begin{tabular}{ccc}
\hline \multirow{2}{*}{ Fungicide } & \multicolumn{2}{c}{ LC50 values $(\mu \mathrm{M})$} \\
\cline { 2 - 3 } & Acute exposure & Continuous exposure \\
\hline AM & No effect at $100 \mu \mathrm{M}$ & $>100$ \\
\hline BO & $>100$ & $>100$ \\
\hline CY & $95 \pm 2$ & $25 \pm 2$ \\
\hline DI & No effect at $100 \mu \mathrm{M}$ & $58 \pm 6$ \\
\hline FE & No effect at $100 \mu \mathrm{M}$ & $27 \pm 1$ \\
\hline KR & $2.6 \pm 0.1$ & $4.4 \pm 0.1$ \\
\hline ME & No effect at $100 \mu \mathrm{M}$ & $>100$ \\
\hline MY & No effect at $100 \mu \mathrm{M}$ & $26 \pm 1$ \\
\hline PY & $0.15 \pm 0.02$ & $0.06 \pm 0.01$ \\
\hline
\end{tabular}


Table 4.- Intracellular levels of selected fungicides in $\mathrm{CN}$ after $8 \mathrm{~h}$ of exposure at 7 DIV.

\begin{tabular}{cccc}
\hline Fungicide (MW) & $\begin{array}{c}\text { Treatment } \\
(\mu \mathrm{M})\end{array}$ & $\begin{array}{c}\text { Cellular uptake } \\
(\mathrm{ng} / \mathrm{mg} \text { protein })\end{array}$ & \% Cellular uptake \\
\hline AM (275) & 100 & $980.0 \pm 1.8(3.6 \mathrm{nmol} / \mathrm{mg} \mathrm{prot})$ & $0.73 \pm 0.02$ \\
CY (325) & 100 & $9115 \pm 1526(28 \mathrm{nmol} / \mathrm{mg} \mathrm{prot})$ & $6.0 \pm 1.0$ \\
KR (313) & 10 & $86 \pm 3(0.3 \mathrm{nmol} / \mathrm{mg} \mathrm{prot})$ & $0.54 \pm 0.02$ \\
PY (388) & 1 & $37 \pm 5(0.095 \mathrm{nmol} / \mathrm{mg} \mathrm{prot})$ & $2.14 \pm 0.27$ \\
\hline
\end{tabular}


Click here to download high resolution image
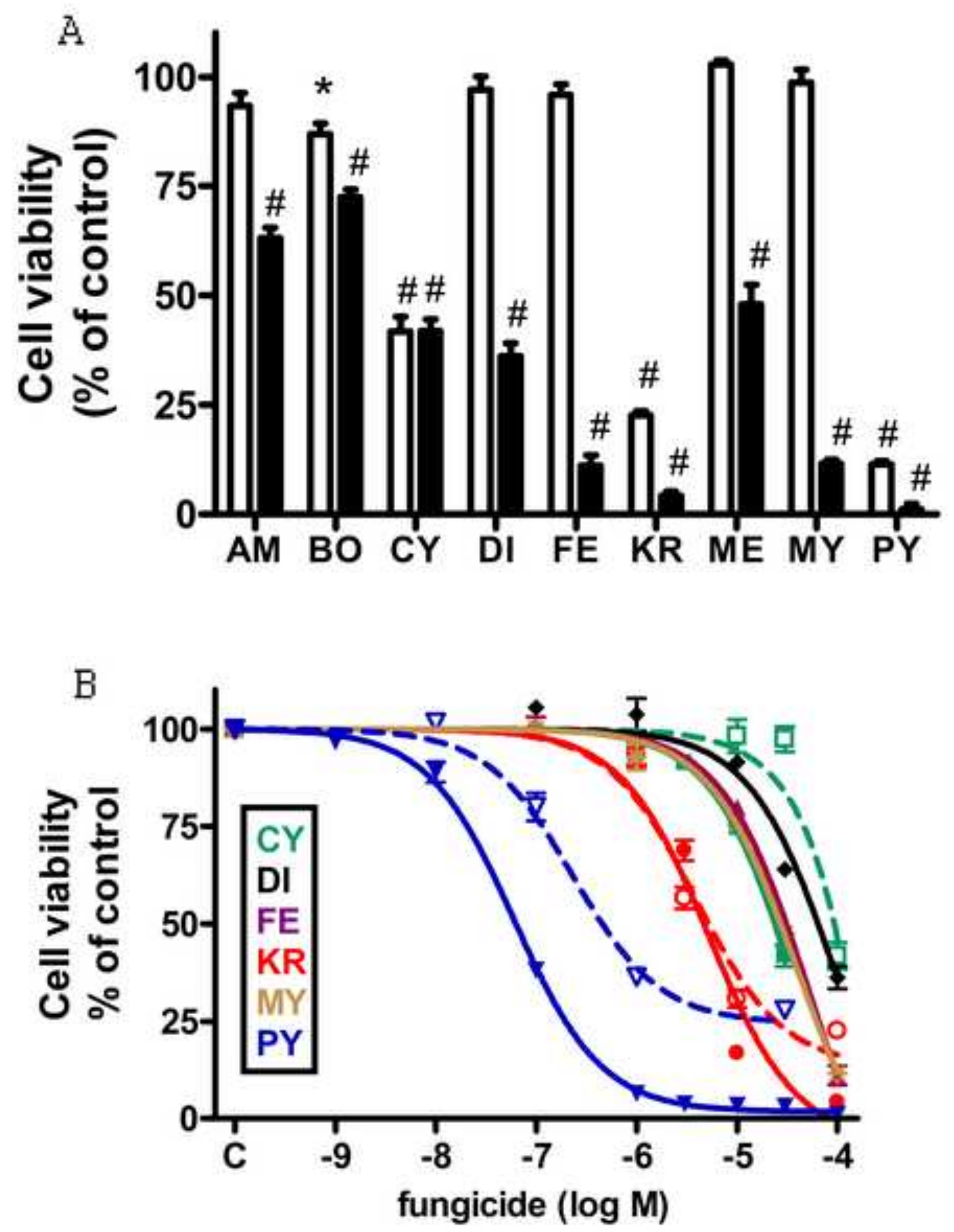
Figure 2
Click here to download high resolution image
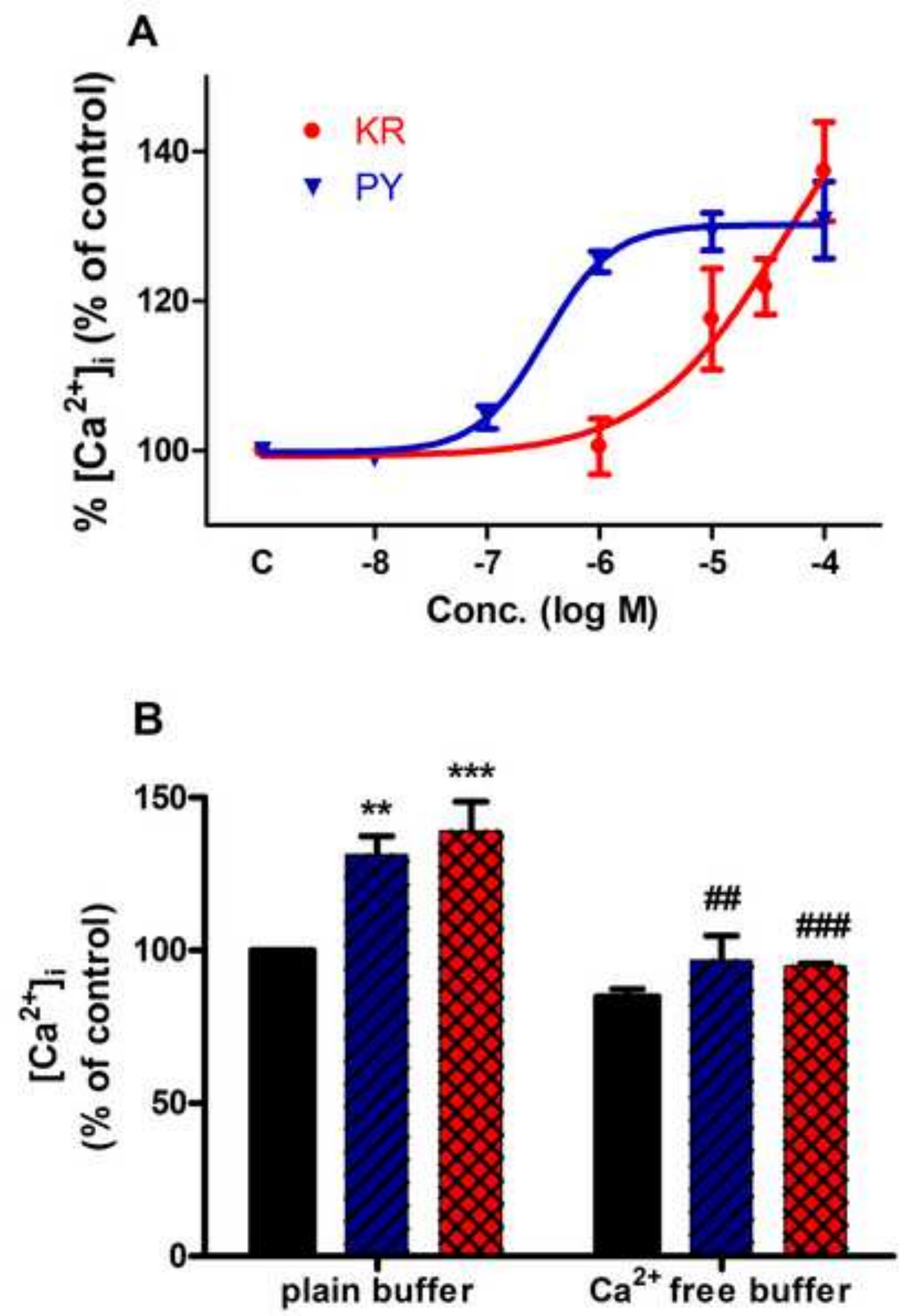
Click here to download high resolution image

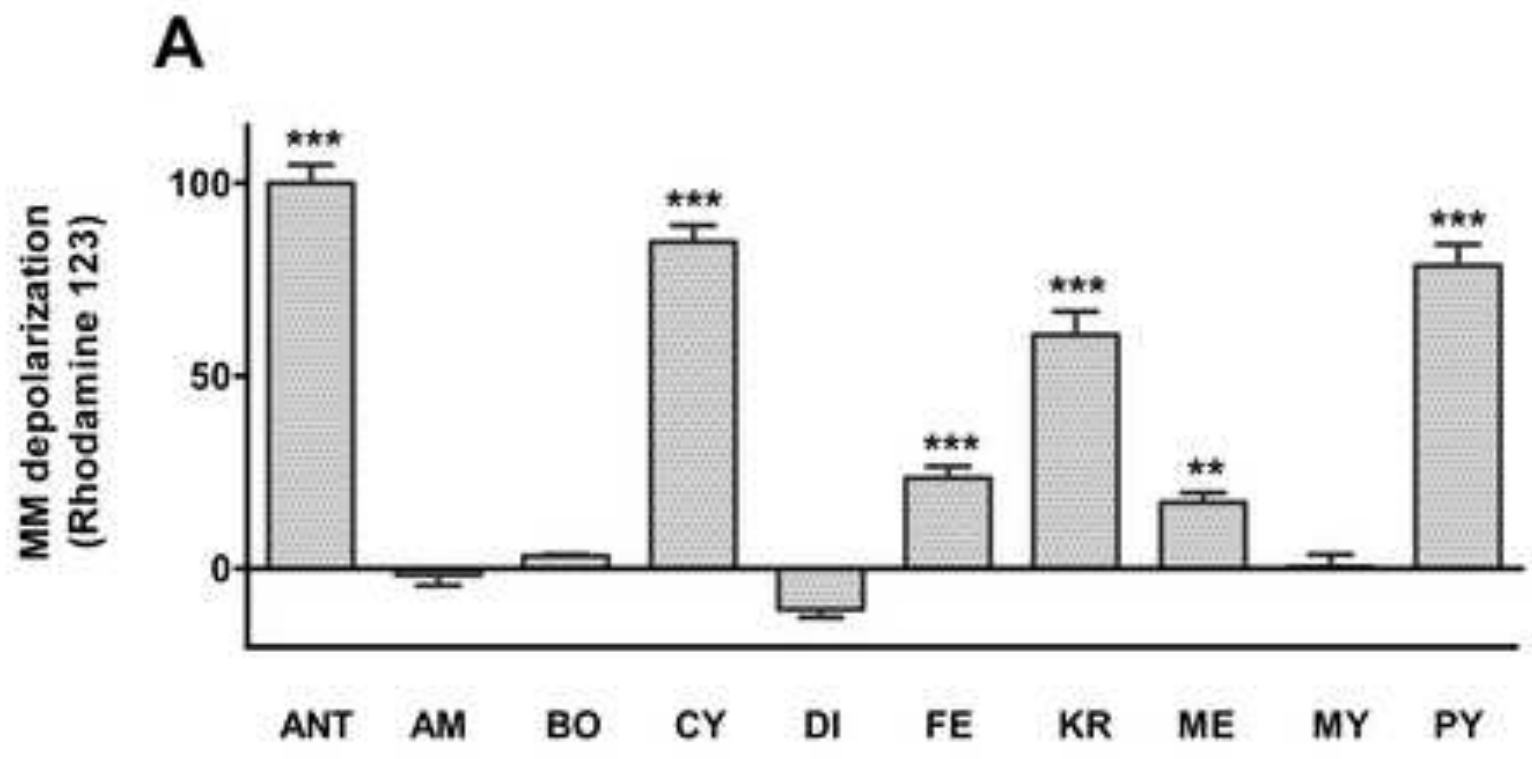

B

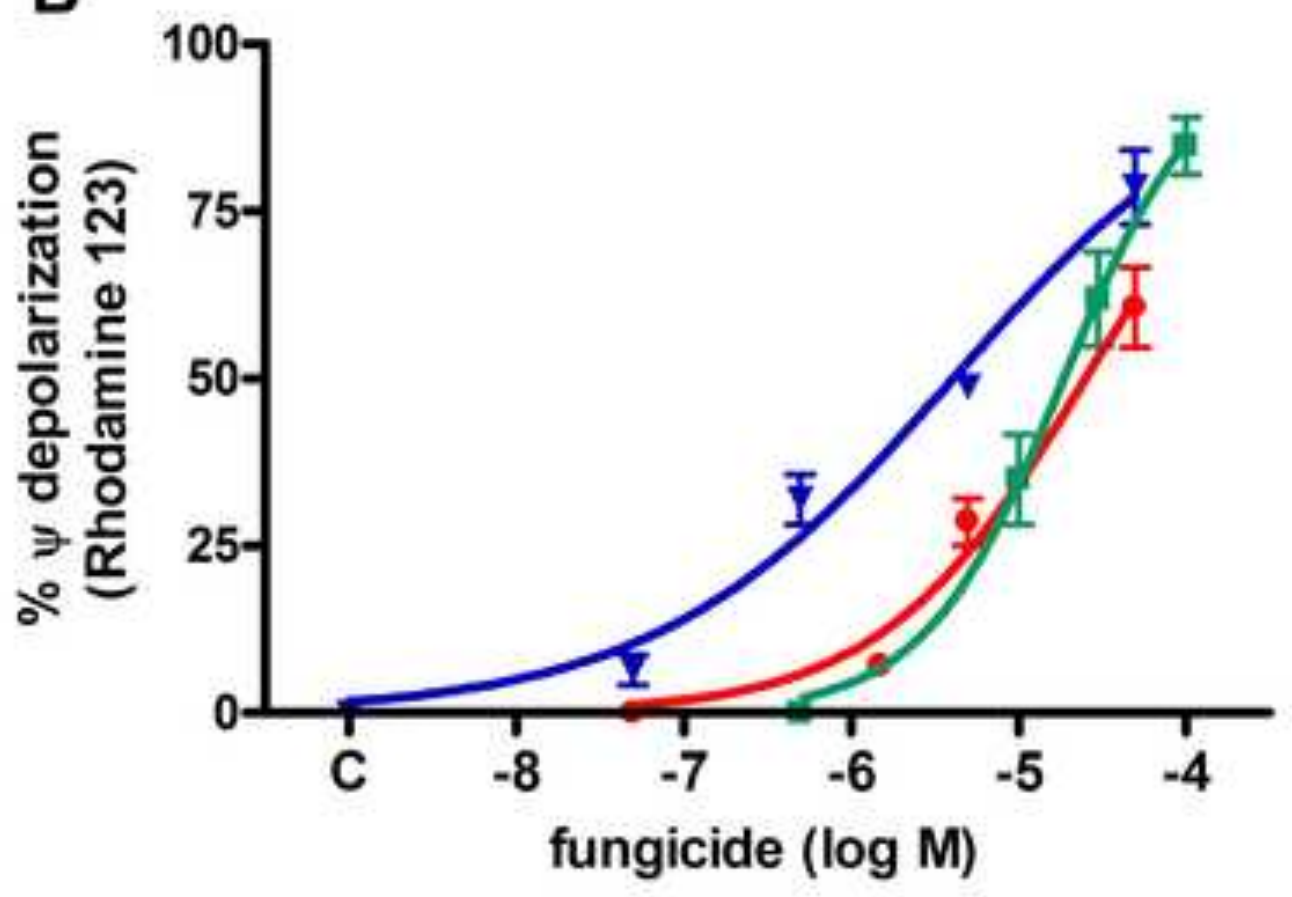


Click here to download high resolution image

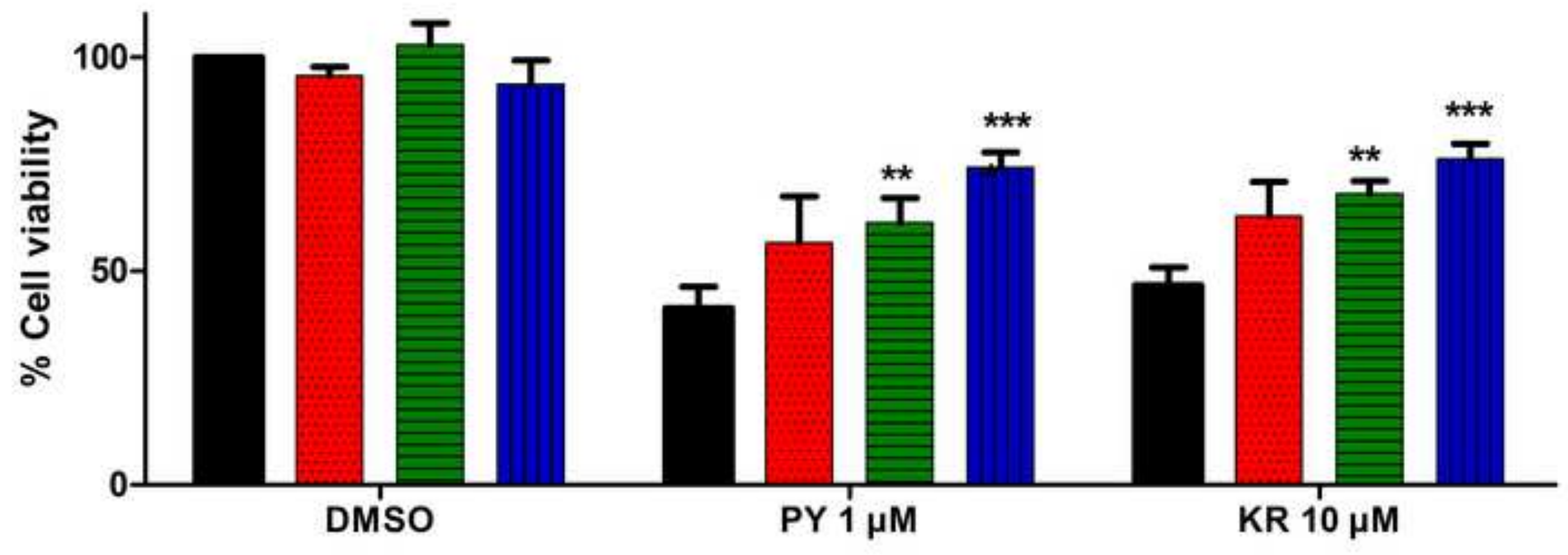

